\title{
Relation of Serum Antioxidants in patients with Periodontal Disease Status
}

\author{
Jehan A. Mohammad \\ Department of Pharmaceutical Science / College of Pharmacy \\ University of Mosul
}

Received

28 / $06 / 2009$
Accepted

09 / 09 / 2009

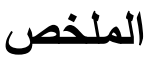

هذه الدراسة تم قياس مستوى بعض مضادات الاكسدة (الكلوتاثايون، فيتامين C، فيتامين E ستة وخمسون شخصاً قسموا إلى مجموعتين، المجموعة الأولى تضم (30) مريضاً

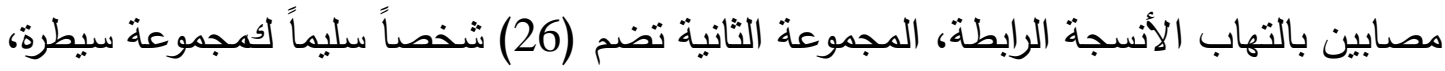
المجموعة الأولى قسمت أيضاً إلى مجموعنين فرعيتين، المجموعة الأولى (IA) مدخنين والمجموعة الثانية (IB) غير مدخنين.

نم مقارنة مستويات مضادات الأكسدة بين المجموعة الأولى والثانية وأظهرت النتائج ان

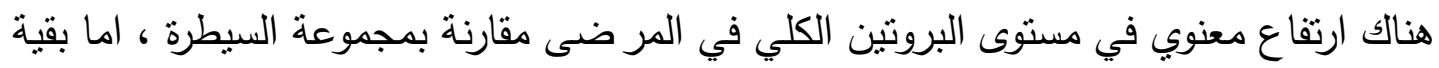

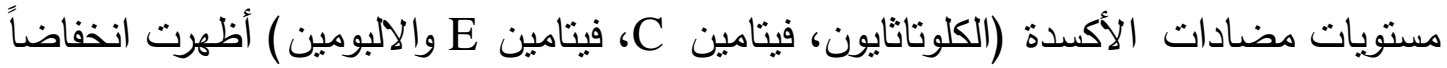

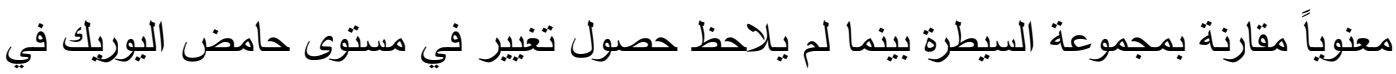

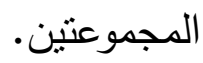

شملت هذه الدراسة أيضاً قياس مستويات مضادات الأكسدة التي فحصت في المرضى

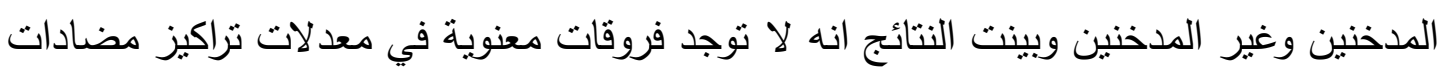

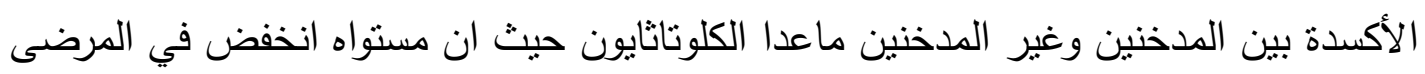
المدخنين مقارنة مع غير المدخنين.

\footnotetext{
Abstract

The study was conducted to investigate the levels of some antioxidants (Glutathion, Vitamin C, Vitamin E, Uric acid, Total protein and Albumin) in serum.
} 
Fifty six subjects were divided into two groups; group I involves (30) patients with periodontal disease and group II involves (26) healthy subjects (control). Group I was also subdivided into two subgroups; group IA (smokers) and group IB (nonsmokers).

Analysis of the results showed that there was a significant increase in the level of total protein in patients in comparison with control group. Antioxidant levels were significants decreased in patients with control (Glutathion, Vitamin C, Vitamin E and Albumin). There was no difference in the level of uric acid between the two groups.

The study also included the measurement of the levels of the investigated antioxidants in smokers and non smokers patients. The results indicated that there was no significant differences in the mean concentrations of antioxidant between smokers and non smokers except for glutathione level, where there was significant decrease in smoker in comparison with non smoker patients.

\section{Introduction}

Periodontitis, an inflammatory disorder of the periodontium damages the bone connective tissue that supports the teeth. Periodontal disease is one of the most commonly reported chronic adult conditions. The disease state ranges from gingivitis to periodontitis and advanced periodontitis ${ }^{(1)}$.

Chronic periodontitis is an inflammatory disease that affects 10$15 \%$ of the developed world population and is the major cause of tooth loss in adults ${ }^{(2)}$.

The predominant inflammatory cell (96\%) within the healthy connective tissues and epithelium of the gingiva is the polymerphonuclear leukocyte (PMNL) ${ }^{(3)}$. In aggressive and chronic forms of periodontitis, PMNLs appear to be functionally activated and exhibit increased production of reactive oxygen species (ROS). These molecules are reported to be capable of inducing periodontal tissue destruction and are associated with osteoclastic bone resorption ${ }^{(4)}$.

The degree to which ROS influence the progression of periodontal diseases is as yet unclear, but their role cannot be considered in isolation, given the range of antioxidant species that protects against excess ROS activity and maintains a delicate equilibrium within host tissues contain $^{(5)}$.

The human body does contain an array of antioxidant defense mechanisms (non enzymatic and enzymatic antioxidants) to remove harmful ROS as soon as they are formed and to prevent their deleterious effects $^{(6)}$. The non enzymatic antioxidants include vitamins E,A,C and reduced glutathione $(\mathrm{GSH})$, while the enzymatic antioxidants include super oxide dismutase (SOD), catalase (CAT), glutathione peroxidase (GSHPX) and Glutathione Reductase (GR) ${ }^{(7)}$. 
Antioxidants are present in all body fluids and tissues, and protect against endogenously -formed free radicals, usually produced by leakage of the electron transport system. Antioxidant enzymes such as superoxide dismutase and glutathione peroxidase provide protection within cells whilst low-molecular-weight scavenging antioxidants are present in extracellular fluid. These include ascorbic acid, $\alpha$-tocopherol and $\beta$ carotene. In addition, dietary-derived components such as uric acid, nonprotein thiols and glutathione also act as antioxidants ${ }^{(8)}$, as does albumin found in plasma and saliva ${ }^{(9)}$. Ascorbic acid is believed to be the major aqueous antioxidant, whilst $\alpha$-tocopherol protects against lipid peroxidation. The nature and activity of antioxidants in plasma and fluids, such as those lining the epithelial surface of the lungs, have been extensively characterized ${ }^{(10)}$. However, saliva has received less interest and research remains limited ${ }^{(11)}$.

Hence, the present study was planned to determine the relationship between total glutathione, vitC,vitE, Albumin, total protein and uric acid levels in serum in cases of healthy periodontium and periodontitis.

\section{Material and methods}

Venous blood $(10 \mathrm{ml})$ was collected from (56) male subjects that were chosen for this study. The blood samples was collected in disposable plain tube without anticoagulant and incubated in water bath at $\left(37^{\circ} \mathrm{C}\right.$ ) for $(10)$ minutes to allow the blood to clot. Centrifugation was then done at (4000)xg for (15) minutes. Serum samples were transferred immediately by micropipette to other plain tubes and stored at $\left(-20^{\circ} \mathrm{C}\right)$, waiting for analysis. (30) Patients with chronic periodontitis from hospitals and private clinics in Mosul, with an age of (35-60) years were classified as (Group I), (26) subjects with an age of (35-60) years were considered as (Group II). The (30) patients were divided into two sub groups smokers and non smokers; group IA, group IB.

- Glutathion was determined photometrically using Ellman's reagent ${ }^{(12,13)}$.

- Vitamin C was determined photometrically, using 2,4-dinitrophenyl hydrazine $^{(14)}$.

- Vitamin E was measured according to Emmeric-Engel reaction ${ }^{(15)}$

- Serum uric acid was determined using phosphotungstic acid $\operatorname{method}^{(16,17)}$

- Serum total protein was determined by biuret method ${ }^{(18)}$ using kit manufactured by RANDOX (United Kingdom).

- Serum albumin was determined using dye binding method ${ }^{(19)}$ manufactured by RANDOX (U.K.). 


\section{Results}

There were a singnificant decrease in the levels of glutathione, vitamin $\mathrm{C}$, vitamin $\mathrm{E}$ and albumin in patients group compared to controls as shown in (Table 1). The results also showed that total protein levels was significantly increased in patients compared with control. In case of uric acid level there was no significant difference between the two groups.

Table (1): The mean of some biochemical parameters in group (I) and group (II)

\begin{tabular}{|l|c|c|c|}
\hline \multirow{2}{*}{$\begin{array}{c}\text { Biochemical } \\
\text { parameters }\end{array}$} & $\begin{array}{c}\text { Group II } \\
\text { Control (No.=26) }\end{array}$ & $\begin{array}{c}\text { Croup I } \\
\text { Patient (NO.=30) }\end{array}$ & \multirow{2}{*}{ P-value } \\
\hline Glutathion $\boldsymbol{\mu}$ mole/L & $15.42 \pm 0.290$ & $11.00 \pm 0.22$ & $0.000_{(\mathrm{S})}$ \\
\hline Vitamins E $\boldsymbol{\mu}$ mole/L & $16.71 \pm 0.20$ & $12.02 \pm 0.15$ & $0.000_{(\mathrm{S})}$ \\
\hline Vitamins $\mathrm{C} \boldsymbol{\mu}$ mole/L & $51.52 \pm 0.56$ & $39.34 \pm 0.69$ & $0.000_{(\mathrm{S})}$ \\
\hline Uric acid $\boldsymbol{\mu}$ mole/L & $301.63 \pm 11.27$ & $324.00 \pm 10.1$ & $0.189_{(\mathrm{NS})}$ \\
\hline Total protein g/L & $73.00 \pm 0.87$ & $93.75 \pm 1.5$ & $0.000_{(\mathrm{S})}$ \\
\hline Albumin g/L & $49.75 \pm 0.60$ & $39.62 \pm 0.4$ & $0.0000_{(\mathrm{S})}$ \\
\hline $\mathrm{S}=$ significant & & \\
$\mathrm{NS}=$ non- significant & & & \\
\end{tabular}

The results in Table (2) demonstrate the comparison between levels of the investigated biochemical parameters in group IA and group IB. There were significant decrease in the levels of glutathione in group IA (smokers) compared with group IB (non smokers). In case of vitamin C, and vitamin $\mathrm{E}$ their levels were not significantly decreased in either groups (Table II). However, total protein, uric acid and albumin levels were not significantly increased in group IA than group IB.

Table (2): The mean levels of some biochemical parameters between group (IA) and group (IB)

\begin{tabular}{|l|c|c|c|}
\hline \multirow{2}{*}{$\begin{array}{c}\text { Biochemical } \\
\text { parameters }\end{array}$} & \multicolumn{2}{|c|}{ Mean \pm SE } & \multirow{2}{*}{ P-value } \\
\cline { 2 - 3 } & group (IA) & group (IB) & \\
\hline Glutathion $\boldsymbol{\mu}$ mole/L & $10.71 \pm 0.31$ & $11.37 \pm 0.24$ & $0.027_{(\mathrm{S})}$ \\
\hline Vitamins $\mathrm{E} \boldsymbol{\mu}$ mole/L & $11.79 \pm 0.21$ & $12.15 \pm 0.18$ & $0.159_{(\mathrm{NS})}$ \\
\hline Vitamins $\mathrm{C} \boldsymbol{\mu}$ mole/L & $39.01 \pm 0.90$ & $39.98 \pm 0.92$ & $0.446_{(\mathrm{NS})}$ \\
\hline Uric acid $\boldsymbol{\mu}$ mole/L & $338.80 \pm 16.3$ & $325.53 \pm 12.83$ & $0.361_{(\mathrm{NS})}$ \\
\hline Total protein g/L & $94.01 \pm 1.96$ & $92.98 \pm 2.00$ & $0.703_{(\mathrm{NS})}$ \\
\hline Albumin $\mathrm{g} / \mathrm{L}$ & $39.97 \pm 0.44$ & $39.39 \pm 0.72$ & $0.491_{(\mathrm{NS})}$ \\
\hline
\end{tabular}

$\mathrm{S}=$ significant

$\mathrm{NS}=$ non- significant 


\section{Discussion}

Diseases of the periodontal tissues are among the most widespread inflammatory disorders worldwide and are a major cause of tooth loss in the adult population ${ }^{(1)}$.

Several reports have demonstrated the ability of periodontopathogens and their products to induce the generation of reactive oxygen species (ROS) by polymorphonuclear leukocytes.

Leukocytes are recognized as a particularly rich source of ROS, which in the absence of suitable antioxidants in the crevicular space can lead to tissue damage ${ }^{(20,21)}$.

Vitamin $\mathrm{C}$ is a powerful reducing agent and an important water soluble vitamin for humans and certain other animals. it has been shown to scavenge $\mathrm{O}_{2}^{\circ}, \mathrm{H}_{2} \mathrm{O}_{2}, \mathrm{OH}^{*}$, aqueous peroxy radicals and singlet oxygen. Vitamin $\mathrm{C}$ also protects plasma lipids against lipid peroxidation and has an important role in the regeneration of $\alpha$-tocopherol ${ }^{(22)}$. Vitamin $\mathrm{C}$ a potent antioxidant and major player in the synthesis of collagen, vitamin $\mathrm{C}$ is essential for healthy gums.

The results indicated a strong and consistent inverse association between serum vitamin $\mathrm{C}$ concentrations and the prevalence of periodontitis $^{(2)}$.

Uric acid appears to be the dominant antioxidant present in saliva and displays a concentration similar to that of serum. Other salivary antioxidants included ascorbic acid and albumin, but concentrations of these are lower than that of serum ${ }^{(23)}$.

Serum albumin level is a practical marker of general health status as it demonstrates. The severity of an underlying disease and mortality in the elderly. Inflammation and malnutrition both reduce albumin concentration by decreasing its rate of synthesis. Albumin concentration is associated with nutrition and inflammation ${ }^{(24)}$.

The results of present study showed that the levels of antioxidants (vit C, E, Albumin and glutathione) will decrease in group I (periodontal disease patients) comparing with their levels in group II (healthy individuals), while for total protein and uric acid their levels increased in group I comparing with group II as shown in (Table 1).

For vit C: The reduction of the level of vit $\mathrm{C}$ in group I might be due to gingival bleeding ${ }^{(25)}$. The results of this parameter were in good agreement with the results found by other investigators ${ }^{(2,7,11)}$.

For vit E: The reduction of the level of vitamin $\mathrm{E}$ in group I might be due to that vitamin $\mathrm{E}$ is a lipophilic antioxidant that forms the first line of defense against the peroxidation of the cell membrane polyunsaturated fatty acid ${ }^{(26)}$. The results of this parameter were in good agreement with the results found by other investigators ${ }^{(7,27)}$. 
For glutathion: The reduction of the level of glutathion in group I might be due to that glutathion, an intracellular antioxidant, serves many biological functions including the prevention of oxidative damage, removal of hydroperoxides, and detoxification and stabilization of biological membranes ${ }^{(6)}$. It is a major source of reducing power for the removal of $\mathrm{H}_{2} \mathrm{O}_{2}$ in the reaction catalyzed by glutathion peroxidase ${ }^{(7)}$. The results of this parameter were in good agreement with the results found by other investigator ${ }^{(4,7,28)}$.

A strong synergy between vitamins $\mathrm{E}$ and $\mathrm{C}$ and glutathion has been reported, dietary supplementation of vitamin $\mathrm{C}$ is reported to increase plasma vitamin E levels ${ }^{(29)}$. Similarly, the administration of vitamin $\mathrm{E}$ enhances the plasma levels of ascorbate and erythrocyte glutathione levels ${ }^{(30)}$.

Regeneration of $\alpha$ - tocopherol is dependent on ascorbic acid and glutathione. A decrease in the levels of these two antioxidants might be responsible for low vitamin E levels in the plasma and erythrocytes of periodontitis sufferes. Depletion of glutathione could be related to low levels of vitamin $\mathrm{E}$ and ascorbate, since these two antioxidants present the oxidation of glutathion ${ }^{(7)}$.

For uric acid: These results were in agreement with the results found by other investigators ${ }^{(27,31)}$.

For total protein: The increase level of total protein in group I might be due to leakage of plasma proteins.

For albumin: The decrease of albumin in group I might be due to serum albumin which acted as an antioxidant in scavenging free radicals ${ }^{(32)}$. A low albumin level, therefore might modulate initial cellular damage and help trigger or enhance the irreversible degenerative processes ${ }^{(33)}$. Therefore, in terms of the association between serum albumin concentration and periodontal disease, a decrease serum albumin level might directly influence periodontal disease progression. The results of this parameter were in good agreement with the results found by other investigators ${ }^{(24)}$.

Smokers are more susceptible to advanced and aggressive forms of periodontal disease than non smokers ${ }^{(28)}$.

In this study there were no significant differences between the levels of parameters in smoking and nonsmoking patients except for glutathione where a significant difference in its level was observed (Table 2). 


\section{References}

(1) E. E, Ridgeway, Journal of the American Academy of Nurse practitioners, 12:79-83, (2000).

(2) Iain L. C. Chapple, Mike R. Milward and Thomas Dietrich, The American Society for Nutrition J.Nutr.137:657-664,March,(2007).

(3) Y. Kowashi, F. Jaccard, G. Cimasoni, J. Periodontol Res; 15:1518\},(1980)$.

(4) ILC Chapple, G. Brock, C. Eflimiadi and JB. Matthews, Journal of Clinical Pathology; 55(6), (2002).

(5) ILC. Chapple, Mol. Pathil, 49: 247-55, (1996).

(6) B. Halliwell, Nut. Rev., 52: 523-565, (1994).

(7) Kuppusamy Panjamurthy, Shanmugam Manoharan and Cinnamanoor Rajamani Ramachandran, Cellular and Moleculer Biology Letters, 10:255-264, (2005).

(8) B. Ha lliwell, American Jornal of Medicine, 91, Suppl.3c, 14-22, (1991).

(9) B. Halliwell, Biochmeical pharmacology, 37: 569-571, (1988).

(10) B. Frei, American Journal of Clinical Nutrition, 54:1113s-1118s, (1991).

(11) V. Dean, Sculley, C. Simon and Langley-Evans, Proceeding of the Nutrition Society, 61:137-143, (2002).

(12) J. Sedlak and R. H. Lindsay, "Analytical Biochemistry" P.192. Cited by AL-Zamyle (2001).

(13) N. V. Tietz, "Textbook of Clinical Chemistry" W. B. Saunders Company, Philadelphia, pp.490-491, 1000-1025, (1999).

(14) T. stanley, T David and S. Howerds "selected method for the determination of ascorbic acid in animal cells, tissues and fluids / Method in Enzymology, vol.62. vitamins and coenzymes part D. (1979).

(15) V. Harold, H. Alan and B. Maurice Practical Clinical Biochemistry $5^{\text {th }}$ Ed., Press Ltd., London, Vol.2, 223, (1976).

(16) H. Varley, Practical Clinical Biochemistry, $4^{\text {th }}$ Ed., The White Friars Press Ltd., London and Tonbridge, Great Britain, 160, 205, (1967).

(17) N. W. Tietz, Fundamentals of Clinical Chemistry $2^{\text {nd }}$ Ed., W.B. Saunders Company, Philadelphia, 997, 999, 337, (1982). 
(18) D. T. Plummer, An introduction to Practical Biochemistry, $2^{\text {nd }}$ Ed., Mc Graw-Hill Book Company (U.K.), 142,(1978).

(19) H. Varley, A. H. Gownlock and M. Bell, Practical Clinical Biochemistry, Vol.1, London. Heinemann, 553-555, (1980).

(20) S. Kimuram T. Yonemura and H. Kava, J. Periodontal Res.28:197203, (1993).

(21) R. J. Waddington, R. Moseley and G. Embery, Oral Dis. 6:138151, (2000).

(22) H. Padh, Nutr. Rev. 49:65, (1991).

(23) S. Moore, K A C. Calder, N. J. Millar and C. A. Rice-Evans, Free Radical Research, 21:417-425, (1994).

(24) M. Iwasaki, A. Yoshihara, T. Hirotomi, H. Ogawa, N. Hanada, H. Miyazaki, J. Clin. Periodontol, 35:291-296, (2008).

(25) P. J. Pussinen, T. Leatikainen, G. Alfthan, S. Asikaininen and P. Jousilahti, Clin. Diagn. Lab. Immunol, 10:897-902, (2003).

(26) R. Kashif, S. M. Zaidi and B. Naheed, Clin. Chim. Acta, 340:229233, (2004).

(27) Randa Diab-Ladki, Bern and Pellat, Ramez Chahine, Clinical Oral Investigations. 7(4):103-107, (2003).

(28) Rai. Balwant, Advances in Medical and Dental Sciences, 2(2): 4749, (2008).

(29) K. H. Chen and M. L. Chang, J. Nutr, 108:1616-1620, (1978).

(30) A. D. Bendich, P. Aplito, E. Gabriel and L. J. Miachlin, J.Nutr.114:1558- 1593, (1984).

(31) DDS. Dirk Zieboiz, C.Gesa, DDS.Jager, DDS.Else Hornecker, PhD.; F. Rainer, DDS. Mausberg, PhD., The Journal of Contemporary Dental Practice Volume 8, No.5, (2007).

(32) B. Halliwell and J. M. Gutteridge, Archives of Biochemistry and Biophysics, 280, 1-8, (1990).

(33) M. C. Corti, J. M. Guralnik, M. E. Salive and J. D. Sorkin, The Journal of the American Medical Association, 272: 1036-1042, (1994). 